\title{
PENINGKATAN KUALITAS PEMBELAJARAN IPS MELALUI PENERAPAN METODE PROBLEM BASED LEARNING DI SMP NEGERI 15 KOTA YOGYAKARTA
}

\author{
Mu'aini \\ Prodi Sejarah FKIP Universitas Muhammadiyah Mataram \\ email: wirani.muaini@yahoo.com
}

\begin{abstract}
Abstrak
Penelitian ini merupakan penelitian tindakan kelas dengan Kemmis \& Taggart desain dilakukan dalam 3 siklus. Subyek penelitian adalah 35 siswa. Kolaborator penelitian ini adalah guru dan peneliti sebagai pengamat. Pengumpulan data dilakukan melalui observasi, tes, wawancara, dan catatan lapangan, dan dianalisis secara kualitatif dengan teknik yang dikembangkan oleh Miles dan Huberman. Hasil penelitian menunjukkan bahwa proses pembelajaran IPS dengan menerapkan metode pembelajaran berbasis masalah dapat meningkatkan kualitas belajar IPS dalam proses pembelajaran dan hasil pembelajaran. Peningkatan kualitas pembelajaran dapat diamati dan dibuktikan dengan peningkatan kegiatan belajar sebanyak 74,69\% . siklus I, 77,13\%. Siklus II, dan 91,83\% pada Siklus III. Hasil belajar siswa pada siklus I adalah 67,00 rata-rata, sedangkan siswa mencapai KKM yang 45. 6\%, pada siklus II meningkat rata-rata untuk 71.00 , sedangkan siswa mencapai KKM yang 57. 14\%; dan di Siklus III meningkat menjadi 80. 42 dengan semua siswa (100\%) mencapai KKM. Berdasarkan hasil penelitian dapat disimpulkan bahwa penerapan metode pembelajaran berbasis masalah dapat meningkatkan kualitas Ilmu Sosial pembelajaran di kelas D delapan di SMP Negeri 15 Yogyakarta.
\end{abstract}

Kata kunci: pembelajaran berbasis masalah, kualitas pembelajaran, sosial studi belajar 


\section{Abstract}

This research is classroom action research study with Kemmis \& Taggart design conducted in three cycles. The subjects of the research are 35 students of year-8. The collaborator of this research is the teacher of year-8 as the conductor of the treatment and the researcher as an observer. The data was collected through observations, tests, interviews, and field notes, andanalyzed qualitatively by the techniques developed by Miles and Huberman.

The results of research show that the learning process of Social Studies by implementing problem-based learning method could improve the quality of Social Studies learning in the aspect of learning and learning results. Steps of learning involve indentifying the problems, finding the relevant resources of information, learning independently, analyzing and interpreting the collected data, advancing some of alternative solutions of the problems by integrating the opinion or information to select the problematic solution. The improvement of learning quality could be observed and proved by the increases of learning activities as much as $74.69 \%$ in Cycle I, 77.13\%. in Cycle II, and 91.83\% in Cycle III. The learning result of students in Cycle I was 67.00 in average, while the students achieving KKM were 45. $6 \%$,in Cycle II it increased average to 71.00 , while the students achieving KKM were 57. 14\%; and in Cycle III it increased to 80. 42 with all students (100\%) achieving the KKM. Based on the result of the research it can be concluded that the implementation of problem-based learning method can improve the quality of Social Studies learning in the eighth grade D at SMP Negeri 15 Yogyakarta.

Key Words: Problem-based learning, learning quality, social studies learning

\section{Pendahuluan}

Standar proses pendidikan merupakan pendorong untuk memperbaiki dan meningkatkan kualitas pembelajaran yang selama ini jauh ketinggalan oleh negara-negara lain. Peningkatkan kualitas pembelajaran dapat dimulai dari menganalisis setiap komponen yang dapat dianggap sangat mempengaruhi dalam proses pembelajaran. Proses pembelajaran guru merupakan komponen yang sangat penting, sebab keberhasilan pelaksanaan proses pendidikan sangat tergantung 
pada guru sebagai ujung tombak, yang berhubungan langsung dengan siswa sebagai subjek dan objek belajar.

Kegiatan guru membimbing siswa sangat diharapkan karena berdampak pada keberhasilan siswa. Selain itu, keberhasilan pembelajaran tidak hanya dilihat dari hasil belajar yang dicapai oleh siswa, akan tetapi juga dari segi proses belajarnya. Hasil belajar pada dasarnya merupakan akibat dari suatu proses belajar, sehingga optimalnya hasil belajar siswa bergantung pula pada kualitas poses pembelajaran. Demikian pula, dalam pembelajaran Ilmu Pengetahuan Sosial (IPS) yang diharapkan di sekolah pelaksanaannya mengikuti prinsip belajar aktif. Sebagai landasan penguraikan apa yang dimaksud dengan belajar menurut Ngalim Purwanto, (2007: 84) “belajar adalah setiap perubahan yang relatif menetap dalam tingkah laku yang terjadi sebagai suatu hasil dari latihan atau pengalaman".

Peran guru dalam membantu siswa untuk aktif terlibat dalam proses pembelajaran sangat diharapkan. Guru harus memiliki kemampuan profesional menciptakan kualitas pembelajaran untuk mendorong siswa berpartisipasi aktif. Menurut Rice dan Bishoprick, (Ibrahim, 2004: 5) guru profesional adalah guru yang mengelola dirinya dalam melaksanakan tugas-tugasnya seharihari. Profesionalisasi guru dipandang sebagai satu proses yang bergerak dari ketidaktahuan (ignorance) menjadi tahu, dari ketidakmatangan (immaturity) menjadi matang, dan diarahkan orang lain (other-directedness) menjadi mengarahkan diri sendiri. Dengan kata lain guru profesional adalah orang yang memiliki kemampuan dan keahlian khusus dalam bindang keguruan sehingga ia mampu melakukan tugas dan fungsinya sebagai guru dengan kemampuan maksimal (Kunandar, 2007: 46-47). 
Tugas guru bukan hanya mengajar untuk menyampaikan materi pelajaran, akan tetapi suatu proses mengubah perilaku siswa sesuai dengan tujuan yang diharapkan. Guru dituntut mencari tahu terus-menerus bagaimana peserta didik itu belajar. Maka, apabila ada kegagalan peserta didik, guru mencari penyebabnya dan mencari jalan keluar bersama peserta didik bukan mendiamkannya atau bahkan menyalahkannya. Sikap yang harus senantiasa dipupuk adalah kesedian untuk mengenal diri dan kehendak untuk memurnikan keguruannya.

Proses pembelajaran terdapat kegiatan membimbing siswa agar berkembang, melatih keterampilan baik keterampilan intelektual maupun keterampilan motorik, sebagai pengkaitan pengetahuan baru pada struktur kognitif baru yang sudah dimiliki siswa. Pengkaitan-pengkaitan ini akan membentuk struktur kognitif baru yang lebih mantap, yang dapat dipandang sebagai hasil belajar.

Hasil observasi awal proses pembelajaran di kelas diarahkan kepada kemampuan menghafal informasi dan penugasan. Otak siswa dipaksakan tetapi siswa tidak untuk mengingat dan menimbun berbagai informasi yang diingat dan menimbun berbagai informasi tanpa dituntut memahami informasi yang diingatnya itu untuk menghubungkan dengan kehidupan seharihari. Akibatnya, ketika anak didik lulus dari sekolah, mereka pintar teoritis tetapi siswa miskin aplikasi. Pendidikan di sekolah menjadi terlalu menjejali otak siswa dengan berbagai bahan ajar yang harus dihafal. Pendidikan tidak diarahkan untuk mengembangkan dan membangun karakter serta potensi yang dimilikinya. Dengan kata lain pendidikan kita, proses pendidikan kita tidak diarahkan membentuk manusia yang cerdas, memiliki kemampuan memecahkan masalah hidup, serta tidak diarahkan 
untuk membentuk manusia kreatif dan inovatif. Proses pembelajaran di SMP Negeri 15 yang masih rendah dikarenakan guru belum menggunakan metode yang berpariatif. Siswa kurang aktif mengkonstruksi pengetahuan baru dalam proses pembelajaran IPS. Bayak siswa yang belum mendapatkan hasil belajar yang optimal dikarenakan masih berada dibawah kreteria ketuntasa minimal.

Selain hal tersebut, teramati pula bahwa guru terfokus pada penyampaian materi-materi yang akan diujikan saja sehingga kualitas pembelajaran belum maksimal. Metode yang digunakan masih menoton dan belum menerapkan metode pembelajaran yang bervariasi dalam pembelajaran IPS. Pembelajaran tidak berpusat pada siswa tetapi masih berpusat pada guru (techercentered learning). Dalam proses pembelajaran IPS guru metode belum menggunakan problem based learning untuk meningkatkan kualitas pembelajaran IPS. Kondisi belajar mengajar belum dapat merubah secara nyata wawasan dan perilaku akademik. Hal ini dapat lihat dari kualitas penalaran dan pemahaman siswa pada hasil belajar siswa pada ujian semester satu rata-rata 63,85 padahal Kriteria Ketuntasan Minimal (KKM) 67,00.

Sejalan dengan permasalahan di atas, perlu adanya suatu perbaikan yang mengarah pada upaya peningkatan kualitas pembelajaran yang meliputi unsur kognitif yang ditunjukkan dengan hasil belajar, afektif yang ditunjukakan dengan perilaku siswa dalam proses pembelajaran IPS, sikap positif dengan meningkatnya aktivitas dan motivasi siswa terhadap pembelajaran IPS. Salah satu metode yang dapat digunakan untuk mengatasi masalah kualitas proses pembelajaran adalah melalui metode problem based learning pembelajaran melihat berbagai aspek yang dapat mempengaruhi keberhasilan suatu proses. 


\section{Metode Problem Based-Learning}

Metode problem based learning memusatkan pada aktivitas siswa untuk mengidentifikasi, analisis, dan kerjasama dalam kelompok kecil dengan masalah sebagai stimulus dalam pembelajaran. Pembelajaran dengan metode ini akan menstimulus siswa mengindentifikasi, mendiskusikan, dan menyelidiki permasalahan yang diberikan dalam pembelajaran IPS. Metode problem based learning sesuai dengan bagaimana seharusnya siswa belajar IPS, yang menggunakan pengalaman-pengalaman untuk mengkonstruksi pengalaman baru melalui proses penyelidikan dan penyelesaian masalah.

Masalah yang digunakan, diambil dari permasalahan nyata di lingkungan sosial sesuai dengan materi pembelajaran IPS, sebagai stimulus untuk melatih siswa berikir kritis. Pemikiran kritis akan membentuk kreativitas siswa mengembangkan "keterampilan memproses" secara individu maupun kelompok untuk menyelesaikan suatu permasalahan dalam pembelajaran IPS. Selain itu pembelajaran dengan metode problem based learning akan memfasilitasi siswa untuk mengkonstruksi pengetahuan secara mandiri maupun kerjasama dalam kelompok dan membuat siswa belajar sesuai dengan minat dan perhatiannya yang mengakibatkan siswa semakin termotivasi untuk belajar. Dalam pembelajaran guru merancang pembelajaran yang efektif, efesien, dan menyenangkan. Metode problem based learning diterapkan di SMPN 15 Kota Yogyakarta sebagai salah satu bentuk upaya untuk meningkatkan kualitas pembelajaran IPS sehingga diharapkan berdampak pada prestasi belajar siswa.

Problem Based Learning (PBL) adalah suatu model pembelajaran yang melibatkan siswa untuk memecahkan masalah melalui tahap-tahap metode ilmiah sehingga siswa dapat 
mempelajari pengetahuan yang berhubungan dengan masalah tersebut dan sekaligus memiliki ketrampilan untuk memecahkan masalah (Kamdi, 2007: 77). PBL atau pembelajaran berbasis masalah sebagai suatu pendekatan pembelajaran yang menggunakan masalah dunia nyata sebagai suatu konteks bagi siswa untuk belajar tentang cara berpikir kritis dan keterampilan pemecahan masalah, serta untuk memperoleh pengetahuan dan konsep yang esensial dari materi pelajaran.

PBL memiliki karakteristik sebagai berikut: (1) belajar dimulai dengan satu masalah, (2) memastikan bahwa masalah tersebut berhubungan dengan dunia nyata siswa, (3) mengorganisasikan pelajaran seputar masalah, bukan seputar disiplin ilmu, (4) memberikan tanggung jawab yang besar kepada siswa dalam membentuk dan menjalankan secara langsung proses belajar mereka sendiri, (5) menggunakan kelompok kecil, dan (6) menuntut siswa untuk mendemonstrasi-kan yang telah mereka pelajari dalam bentuk produk atau kinerja. Berdasarkan uraian di atas, tampak jelas bahwa pembelajaran dengan model PBL dimulai oleh adanya masalah yang dalam hal ini dapat dimunculkan oleh siswa ataupun guru, kemudian siswa memperdalam pengetahuannya tentang apa yang mereka telah ketahui dan apa yang mereka perlu ketahui untuk memcahkan masalah tersebut. Siswa dapat memilih masalah yang dianggap menarik untuk dipecahkan sehingga mereka terdorong berperan aktif dalam belajar.

Jonassen (1999) mendesain model lingkungan belajar konstruktivistik yang dapat diaplikasikan dalam pembelajaran kontekstual dengan pendekatan problem-based learning. Model tersebut memuat komponen-komponen esensial yang meliputi:(1) pertanyaan-pertanyaan, kasus, masalah atau proyek, (2) kasus- 
kasus yang saling terkait satu sama lain, (3) sumber-sumber informasi, (4) cognitive tools, (5) pemodelan yang dinamis, (6) percakapan dan kolaborasi, (7) dukungan kontekstual/sosial. Masalah dalam model tersebut mengintegrasikan komponenkomponen konteks permasalahan, representasi atau simulasi masalah, dan manipulasi ruang permasalahan.

Kelebihan PBL dibandingkan dengan model pengajaran lainnya adalah 1). mendorong kerjasama dalam menyelesaikan tugas, 2). mendorong siswa melakukan pengamatan dan dialog dengan orang lain, 3). melibatkan siswa dalam penyelidikan pilihan sendiri, 4). membantu siswa menjadi pembelajar yang mandiri. Sama halnya dengan model pengajaran yang lain, PBL juga memiliki beberapa kelemahan dalam penerapannya. kelemahan pelaksanaan PBL yakni 1). Kondisi kebanyakan sekolah yang tidak kondusif untuk pendekatan PBL, 2). Pelaksanaan PBL memerlukan waktu yang cukup lama, 3) Model PBL tidak mencakup semua informasi atau pengetahuan dasar.

Kekurangan PBL, sama halnya dengan model pengajaran yang lain, PBL juga memiliki beberapa kelemahan/hambatan dalam penerapannya (Ricard I Arends dan Ibrahim dalam Rusmiyati, 2007: 17). Kelemahan dari pelaksanaan PBL adalah sebagai berikut:

1) Kondisi kebanyakan sekolah tidak kondusif untuk pendekatan PBL. Dalam pelaksanaannya, PBL memerlukan sarana dan prasarana yang tidak semua sekolah memilikinya. Sebagai contoh, banyak sekolah yang belum memiliki fasilitas laboratorium cukup memadai untuk kelengkapan pelaksanaan PBL. 
JIPSINDO No. 1, Volume 3, Maret 2016

2) Pelaksanaan PBL memerlukan waktu yang cukup lama. Standar 40-50 menit untuk satu jam pelajaran yang banyak dijumpai di berbagai sekolah tidak mencukupi standar waktu pelaksanaan PBL yang melibatkan aktivitas siswa di luar sekolah.

3) Model PBL tidak mencakup semua informasi atau pengetahuan dasar.

Model pembelajaran kooperatif memiliki basis pada teori psikologi kognitif dan teori pembelajaran sosial. Fokus pembelajaran kooperatif tidak saja tertumpu pada apa yang dilakukan peserta didik tetapi juga pada apa yang dipikirkan peserta didik selama aktivitas belajar berlangsung. Informasi yang ada pada kurikulum tidak ditransfer begitu saja oleh guru kepada peserta didik, tetapi peserta didik difasilitasi dan dimotivasi untuk berinteraksi dengan peserta didik lain dalam kelompok, dengan guru dan dengan bahan ajar secara optimal agar ia mampu mengkonstruksi pengetahuannya sendiri. Dalam model pembelajaran kooperatif, guru berperan sebagai fasilitator, penyedia sumber belajar bagi peserta didik, pembimbing peserta didik dalam belajar kelompok, pemberi motivasi peserta didik dalam memecahkan masalah, dan sebagai pelatih peserta didik agar memiliki ketrampilan kooperatif.

\section{Pembelajaran IPS}

Pelajaran di tingkat sekolah dasar dan menengah atau nama program studi di Perguruan Tinggi identik dengan istilah "social studies” (Sapriya, 2009: 19). Istilah IPS di SMP merupakan nama mata pelajaran yang berdiri sendiri sebagai integrasi dari sejumlah konsep disiplin ilmu sosial, humaniora, sains bahkan berbagai isu dan masalah sosial kehidupan Sapriya (2009: 20). Materi IPS untuk jenjang SMP tidak terlihat aspek disiplin ilmu karena lebih 
dipentingkan adalah dimensi pedagogik dan psikologis serta karakteristik kemampuan berpikir peserta didik yang bersifat holistik Sapriya (2009: 20). IPS adalah suatu bahan kajian terpadu yang merupakan penyederhanaan, adaptasi, seleksi dan modifikasi diorganisasikan dari konsep-konsep ketrampilanketrampilan Sejarah, Geografi, Sosiologi, Antropologi, dan Ekonomi (Puskur, 2001: 9). Fakih Samlawi \& Bunyamin Maftuh (1999: 1) menyatakan bahwa IPS merupakan mata pelajaran yang memadukan konsep-konsep dasar dari berbagai ilmu sosial disusun melalui pendidikan dan psikologis serta kelayakan dan kebermaknaannya bagi siswa dan kehidupannya.

Pembelajaran menurut Zamroni (2011: 238) bahwa pembelajaran merupakan interaksi yang melibatkan dua pihak yaitu pendidik dan peserta didik untuk mencapai tujuan yang telah ditentukan, sehingga interaksi komunikasi yang terjadi baik antara sumber belajar, guru dan peserta didik. Pembelajaran IPS merupakan integrasi dari berbagai cabang ilmu sosial seperti sosiologi, sejarah, geografi, ekonomi, politik, hukum dan budaya. Ilmu Pengetahuan Sosial dirumuskan atas dasar realita dan fenomena sosial yang mewujudkan satu pendekatan interdisipliner dari aspek dan cabang ilmu sosial.

Muhammad Numan Sumantri (2001: 44) menjelaskan tentang IPS di tingkat sekolah merupakan suatu penyederhanaan disiplin ilmu-ilmu sosial, psikologi, filsafat, ideologi negara, dan agama yang diorganisasikan dan disajikan secara ilmiah dan psikologis untuk tujuan pendidikan. Maka mata pelajaran IPS di Indonesia ialah penyederhanaan ilmu-ilmu sosial yang disajikan secara ilmiah dan psikologis yang memiliki tujuan untuk bidang pendidikan. 
Pembelajaran IPS lebih menekankan pada aspek pendidikan dari pada transfer konsep karena dalam pembelajaran IPS siswa diharapkan memperoleh pemahaman terhadap sejumlah konsep dan mengembangkan serta melatih sikap, nilai, moral dan ketrampilannya berdasarkan konsep yang telah dimilikinya. IPS juga membahas hubungan antara manusia dengan lingkungannya. Lingkungan masyarakat dimana anak didik tumbuh dan berkembang sebagai bagian dari masyarakat dan dihadapkan pada berbagai permasalahan lingkungan sekitarnya.

Berdasarkan uraian di atas peneliti menyimpulkan bahwa pembelajaran IPS sebagai proses belajar yang mengintegrasikan konsep-konsep terpilih dari berbagai ilmu-ilmu sosial dan humaniora siswa agar berlangsung secara optimal.

\section{Metode Penelitian}

Jenis penelitian yang akan digunakan adalah Penelitian Tindakan Kelas (Classroom Action Research). Penelitian Tindakan Kelas (PTK) merupakan penelitian tindakan yang dilakukan di kelas dengan tujuan memperbaiki kualitas praktik pembelajaran di kelasnya. Penelitian tindakan mengacu pada pendekatan spiral yang merupakan empat langkah kesatuan yang berulang yaitu: perencanaan (planning), pelaksanaan (acting), pengamatan (observing),dan pemikiran kembali (reflencing). Keempat langkah ini terus dilakukan berulang sampai perbaikan yang diharapkan tercapai.

Pihak yang dijadikan subjek penelitian di sini adalah siswa kelas VIII SMP N 15 Yogyakarta. Sedangkan untuk obyek penelitian ini adalah keseluruhan proses dan hasil pembelajaran IPS melalui penerapan model Problem Based Learning di kelas VIII SMP N 15 Yogyakarta dalam upaya meningkatkan kualitas 
pembelajaran dan hasil belajar siswa. Instrumen yang digunakan dalam penelitian tindakan kelas ini adalah lembar observasi dan tes hasil belajar.

1. Lembar observasi

Lembar observasi ini digunakan untuk mengumpulkan data tentang keaktifan siswa dalam pelaksanaan pembelajaran IPS pada saat diterapkan metode Problem Based Learning.

2. Tes Hasil Belajar

Tes yang akan diberikan pada siswa dalam penelitian adalah tes awal siklus (Pre Test) dan tes akhir siklus (Post Test). Tes awal siklus digunakan untuk mengetahui nilai sebelum siklus. Sedangkan tes akhir siklus dimaksudkan untuk mengetahui hasil belajar siswa setelah diterapkan model Problem Based Learning. Materi yang dijadikan bahan tes adalah materi yang diajarkan pada siklus sebelumnya.

\section{Hasil Penelitian}

Data pengamatan keterampilan sosial peserta didik baik individu dan dalam kerja kelompok dianalisis dengan menjumlahkan rata-rata skor peserta didik tiap indikator, kemudian skor tersebut diklasifikasikan menggunakan kriteria sebagaimana disajikan pada Tabel 1 .

Tabel 1.

Skor penilaian mengunakan metode problem based learning

\begin{tabular}{|l|l|l|l|}
\hline No & \multicolumn{1}{|c|}{ Rerata Skor } & \multicolumn{1}{|c|}{$\begin{array}{c}\text { Interval } \\
\text { Nilai }\end{array}$} & \multicolumn{1}{|c|}{ Kategori } \\
\hline 1 & $4,30-5,00$ & $86-100$ & Sangat baik \\
\hline 2 & $3,55-4,25$ & $71-85$ & Baik \\
\hline 3 & $2,80-3,50$ & $56-70$ & Cukup \\
\hline
\end{tabular}




\begin{tabular}{|l|l|l|l|}
\hline 4 & $2,05-2,75$ & $41-55$ & Kurang \\
\hline 5 & $\leq 2,00$ & $\cdot \leq 40$ & $\begin{array}{l}\text { Sangat } \\
\text { Kurang }\end{array}$ \\
\hline
\end{tabular}

Sumber: Penulisan Rapor Kurikulum 2004

Mean biasanya dihitung melalui pembagian jumlah total semua skor dengan jumlah unit skor, berukut rumusan mencari rata-rata penilaian menurut Sutrisno Hadi (2001: 42)

$\mathrm{M}=\frac{\sum \mathrm{X}}{\mathrm{N}}$

$\mathrm{M}=$ Mean atau rata-rata

$\sum \mathrm{X}=$ Jumlah skor dalam suatu distribusi

$\mathrm{N} \quad=$ Jumlah unit-unit skor

Data tentang hasil belajar siswa sebelum tindakan (pre test) digunakan untuk mengetahui nilai siswa sebelum dilaksanakan tindakan dan post test untuk mengukur sejauh mana keberhasilan setelah dilakukan tindakan pada siklus I. Jika hasil pada siklus pertama belum sesuai dengan target maka dilakukan tindakan siklus lanjutan, dan penelitian ini dilakukan 3 siklus.

1. Proses Pelaksanaan Penerapan Metode Problem Based Learning

Pembelajaran dengan menggunakan metode problem based learning memerlukan guru yang dapat memahami dan mampu menyajikan suatu permasalahan yang dapat membangun dan memperluas pengalaman siswa sebelumnya dan responsif terhadap kerangaman tipe pembelejaran siswa. Guru IPS SMP Negeri 15 Yogyakarta ini telah memahami hal itu. Didukung oleh pengalamannya mengajar dan bukti sebagai guru bersertifikasi, menunjukkan bahwa guru mau dan dapat belajar dengan cepat mengenai permasalahan dan solusi apa yang dapat ditawarkan untuk menyelesaikan permasalahan di kelasnya. Guru belum pernah menerapkan metode problem based learning. 
Persentase peningkatan pelaksanaan pembelajaraan dengan menggunakan metode problem based learning pada gambar 1 .

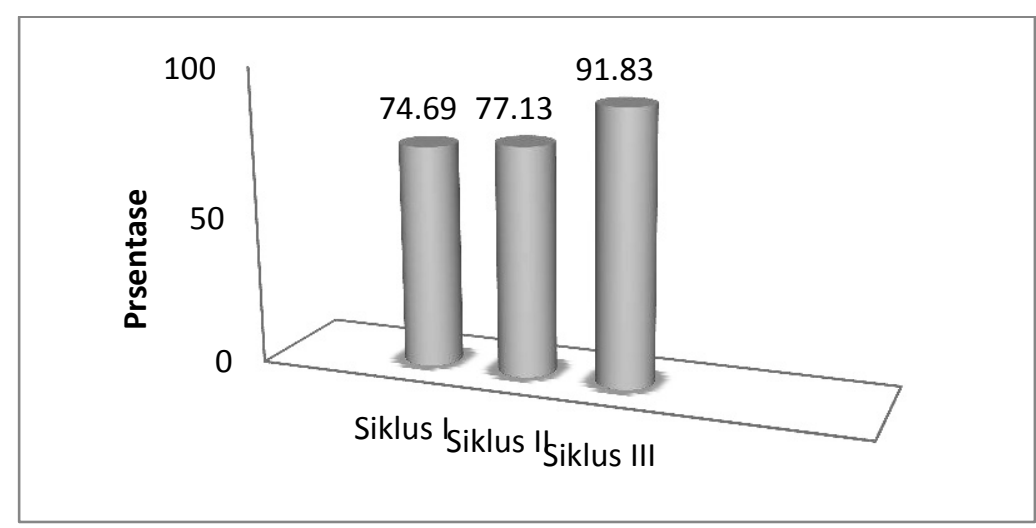

Gambar 1.

Grafik Persentase Peningkatan Pelaksanaan Pembelajaran dengan Metode Problem Based Learning

Dari grafik menujukkan dari siklus ke siklus terjadi peningkatan pelaksanaan pembelajaran. Persentase peningkatan pembelajaran dihitung berdasarkan perbandingan antara banyaknya komponen pembelajaran metode problem based learning yang dilaksankan guru dengan semua komponen pembelajaran metode problem based learning. Penerapan metode problem based learning terdiri dari 7 langkah-langkah yaitu; 1) mengidentifikasi pengetahuan atau kecakapan yang dimiliki (lowest cognitive complexity), 2) mengidentifikasi masalah dan menggali sumber informasi yang relevan (low cognitive complexity), 3) belajar secara mandiri (self-directed learning), 4) menyelidiki dan mengiterprestasi yang terkumpul (medium cognitive complexity), 5) memperioritaskan beberapa alternatif solusi masalah (high cognitive complexity),6) mengitengrasikan pendapat atau data informasi untuk menyeleksi solusi masalah (highest cognitive complexity), 7) refleksi diri (self reflect).

Dari ketujuh langkah tersebut dijabarkan menjadi 16 indikator yang harus dilaksanakan guru dalam proses pembelajaran. Pada siklus I, II, dan III berturut-turut guru 
berhasil melaksanakan komponen metode problem based learningdengan memperlihatkan pelaksanaan dalam penerapan metode problem based learningsebesar pada siklus I 74,69\%, siklus II 77,13\%, dan siklus III 91,83\%. Berdasarkan keterangan komponen yang sulit untuk dilakukan adalah mengidentifikasi masalah dan mencari sumber yang relevan. Hal ini disebabkan siswa masih banyak tidak memiliki buku ajar seperti halnya yang terjadi pada pembelajaran sebelum tindakan, yaitu guru menjelaskan dan siswa mendengarkan.

2. Hasil Belajar Siswa

Hasil belajar siswa yang didapat dari hasil belajar ranah kognitif, ranah afektif dan ranah psikomotor dilihat dari aktivitas siswa dalam kegiatan pembelajaran. Hasil rata-rata nilai hasil belajar tiap-tiap siklus mengalami peningkatan, yaitu nilai ratarata pada siklus I 63,83, siklus II 71,14, dan siklus III 71,14. Demikian halnya dengan ketuntasan belajar oleh siswa dari siklus kesiklus meningkat dan pada siklus III 100\% siswa tuntas belajar. Hasil selengkapnya dapat dilihat pada Tabel 2.

Tabel 2

Rekapitulasi Hasil Belajar Siswa dan Ketuntasan Belajar Siswa pada Siklus, I, II, dan III.

\begin{tabular}{|c|c|c|c|l|c|}
\hline Siklus & $\begin{array}{c}\text { Nilai } \\
\text { Rata- } \\
\text { rata }\end{array}$ & $\begin{array}{c}\text { Siswa } \\
\text { Tuntas } \\
\text { Belajar }\end{array}$ & $\begin{array}{c}\text { Siswa } \\
\text { Belum } \\
\text { Tuntas }\end{array}$ & $\begin{array}{c}\text { Persentase } \\
(\%)\end{array}$ & Keterangan \\
\hline I & 67,00 & 16 & 19 & 45,6 & $\begin{array}{l}\text { Belum } \\
\text { tuntas }\end{array}$ \\
\hline II & 71,14 & 20 & 15 & 57,14 & Belum \\
\hline
\end{tabular}




\begin{tabular}{|c|c|c|c|c|c|}
\hline & & & & & Tuntas \\
\hline III & 80,42 & 35 & 0 & 100 & Tuntas \\
\hline
\end{tabular}

Tabel 2 menunjukkan sudah mengalami peningkatan hasil belajar siswa melalui penerapan metode problem based learning yang diberikan dapat dilihat dari hasil belajar siswa. Jika skor hasil belajar siswa berada di atas KKM yang telah ditetapkan sekolah, maka siswa sudah dikatakan mengalami peningkatan hasil belajar yang telah ditentukan, KKM yang ditetapkan sekolah, yaitu 67,00.

Peningkatan terlihat dari hampir semua siswa, pada siklus I nilai rata-rata 67,00 , skor tertinggi 80 sedangkan skor terendah 55 dan jumlah siswa yang mencapai KKM 16 siswa (5,6\%). Peningkatan pada siklus II dengan nilai rata-rata 71,14 skor tertinggi 85 sedangkan skor terendah 65 dan jumlah siswa yang mencapai KKM 20 siswa (57,14\%).Peningkatan pada siklus III nilai rata-rata 80,42, skor tertinggi 90 sedangkan skor terendah 70 dan jumlah siswa yang mencapai KKM 35 siswa (100\%).

Selain siswa yang tuntas,siswa yang tidak tuntas pada siklus I sebanyak 19 siswa (54,28\%), siswa yang tidak tuntas di karenakan peroleh skor dibawah 67 antara 55-65.Siswa yang tidak tuntas pada siklus II sebanyak 15 siswa $(42,85 \%)$, siswa yang tidak tuntas di karenakan peroleh skor dibawah 67 siswa yang nilainya 65. Siklus III semua siswa sudah mencapai KKM 35 siswa (100\%), semua siswa sudah tuntas di karenakan peroleh skor dibawah 67 tidak ada. Grafik peningkatan ratarata hasil belajar siswa dari siklus I samapai III dapat dilihat pada gambar 2 . 


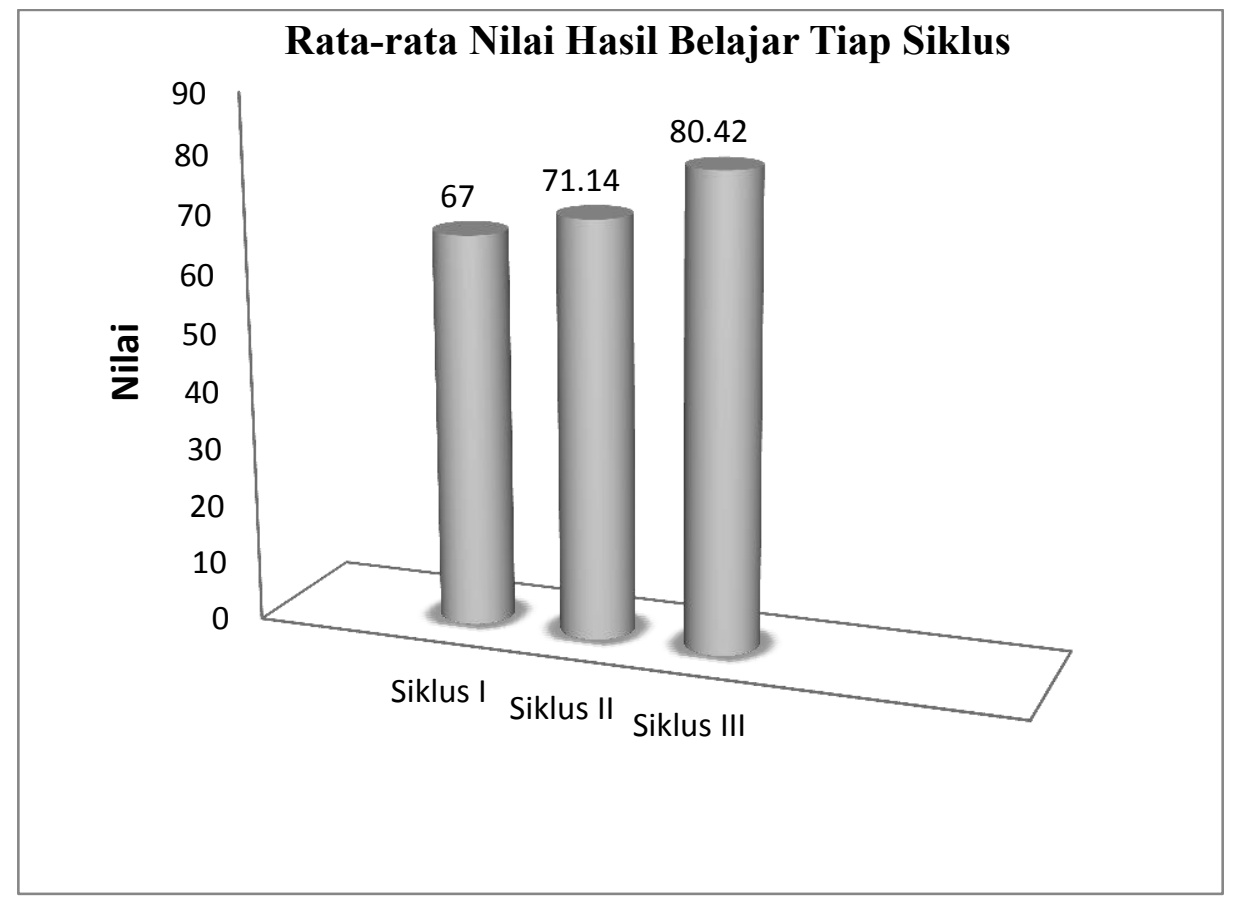

Gambar 2

Grafik Peningkatan Hasil Belajar Siswa pada Pembelajaran IPS Melalui Metode Problem Based Learning

Kriteria keberhasilan minimal yang ditetapkan untuk hasil belajar siswa adalah 67,00 sehingga pada siklus I masih banyak siswa yang belum mencapai KKM, pada siklus II masih ada siswa belum mencapai KKM, dan pada siklus III sudah dapat dikatakan semua siswa sudah mencapai KKM. Peningkatan hasil belajar ini bukan semata-mata siswa dapat memberikan jawaban yang benar, tetapi bagaimana proses siswa menemukan alternatif yang tepat. Alternatif masing-masing siswa menunjukkan proses siswa menyelesaikan masalah yang diberikan.

Hasil penelitian menunjukkan bahwa ada respon siswa terhadap bidang studi pelajaran IPS dengan penerapan metode problem based laerning meningkat dari siklus ke siklus. Melalui metode problem based learning dapat meningkatkan hasil belajar siswa, karena metode tersebut dapat melatih siswa berfikir kritis dalam menyelesaikan masalah menemukan alternatif solusi 
penyelesaian masalah untuk bidang studi pelajaran IPS di SMP Negeri 15 Yogyakarta.

\section{Simpulan}

Penerapan metode problem based learning dapat meningkatkan kualitas pembelajaran IPS di SMP Negeri 15 Yogyakarta. Peningkatan yang terjadi pada guru maupun pada siswa, hal ini dapat dilakukan dengan meningkatkan peran guru sebagai fasilitator, meningkatkan aktivitas siswa dalam aspek mengindentfikasi imasalah, mengemukakan ide-ide alternatif penyelesaian masalah, melakukan kerjasama dengan diskusi kelompok, mempresentasikan hasil diskusi kelompok, bersifat kritis dalam mengikuti pelajaran, menyelesaikan tugas guru dengan tepat waktu dan peningkatan pada hasil belajar siswa.

Sebelum dilakukan penerapan metode problem based learning aktivitas siswa lebih banyak mencatat, mendengarkan, dan menjawab pertanyaan guru. Setelah dilakukan tindakan penerapan metode problem based learning dalam pelaksanaan pembelajaran terjadi peningkatan dari siklus I74,69\%, siklus II 77,13\%, dan siklus III 91,83\%. Pada hasil belajar siswa juga terjadi peningkatan dari siklus I dengan rata-rata 67,00, siklus II rata-rata meningkat menjadi 71,14 dan pada siklus III rata-rata meningkan menjadi 80,42. 
JIPSINDO No. 1, Volume 3, Maret 2016

\section{DAFTAR PUSTAKA}

Ibrahim Baladal. (2008). Peningkatan profesionalisme guru sekolah Dasar. Jakarta: Bumi Aksara

Kemmis, S.,\& McTargaart, R. (1990). The action research planner. Victoria: Deakin University

Kunandar. (2008). Guru profesional implementasi tindakan satuan pendidikan(KTSP) dan sukses dalam sertivikasi guru. Jakarta: Rajawali Pres.

Ngalim Purwanto, M. (2007). Psikologi Pendidikan. Bandung: PT.Roasa Karya.

Sutrisno Hadi. (2001). Statistik. Yogyakarta: Andi Offset. 